\title{
Genomic actions of estrogen receptor $\alpha$ : what are the targets and how are they regulated?
}

\author{
Willem-Jan Welboren, Fred C G J Sweep ${ }^{1}$, Paul N Span ${ }^{1,2}$ \\ and Hendrik G Stunnenberg
}

\author{
Department of Molecular Biology, Faculty of Science, Nijmegen Centre for Molecular Life Sciences, Radboud University Nijmegen, \\ PO Box 9101, HB Nijmegen, The Netherlands \\ Departments of ${ }^{1}$ Chemical Endocrinology and ${ }^{2}$ Radiation Oncology, Radboud University Nijmegen Medical Centre, Nijmegen, \\ The Netherlands \\ (Correspondence should be addressed to H G Stunnenberg; Email: h.stunnenberg@ncmls.ru.nl)
}

\begin{abstract}
The estrogen receptor $\alpha(E R \alpha)$ is a ligand-dependent transcription factor that regulates a large number of genes in many different target tissues and is important in the development and progression of breast cancer. ER $\alpha$-mediated transcription is a complex process regulated at many different levels. The interplay between ligand, receptor, DNA sequence, cofactors, chromatin context, and post-translational modifications culminates in transcriptional regulation by $E R \alpha$. Recent technological advances have allowed the identification of $\mathrm{ER} \alpha$ target genes on a genomewide scale. In this review, we provide an overview of the progress made in our understanding of the different levels of regulation mediated by ER $\alpha$. We discuss the recent advances in the identification of the ER $\alpha$-binding sites and target gene network and their clinical applications.
\end{abstract}

Endocrine-Related Cancer (2009) 16 1073-1089

\section{Introduction}

Estrogens regulate many cellular processes in a wide variety of target tissues during growth, development, and differentiation. Estrogens are mainly involved in the regulation and development of the female reproductive tract but also play a role in the central nervous system, cardiovascular systems, and in bone metabolism (Katzenellenbogen 1996). In addition to their role in physiology, estrogens are also associated with the development and progression of breast cancer (Anderson 2002). In 1896, Beatson discovered that removal of the ovaries resulted in breast cancer remission, connecting for the first time hormones with breast cancer, decades prior to the discovery of estrogens or estrogen receptors (ERs). Seventy years later, O'Malley observed changes in hybridizable RNA upon estrogen stimulation of the chick oviduct, indicating that estrogens regulate transcription (O’Malley et al. 1968). Again several years later a specific estrogen-binding protein was discovered that was present in breast tumors and its expression level could predict the response to endocrine disruption, thereby making the link between cancer and estrogens that was described almost a century before (Jensen et al. 1971, McGuire 1973). The subsequent cloning of the $E R \alpha$ gene and the identification of specific domains demonstrated that $E R \propto$ functions as a ligand-dependent transcription factor (Green et al. 1986, Greene et al. 1986, Kumar et al. 1987). The structures of ER $\alpha$ and its nongenomic regulation have been reviewed extensively (Ruff et al. 2000, Warner \& Gustafsson 2006). This review will focus on the regulation of $E R \alpha$ mediated transcription and on the advances made in the elucidation of its target gene network. Furthermore, the clinical significance and implications of ER $\alpha$ expression and genome-wide chromatin immunoprecipitation (ChIP) profiling is discussed.

\section{Estrogen receptor}

The ER $\alpha$ (NR3A1) is a member of the super family of nuclear receptors, which are ligand-dependent transcription factors. In addition to $\mathrm{ER} \alpha$, the family includes other steroid hormone receptors such as the androgen receptor (AR, NR3C4), the glucocorticoid 
receptor (GR, NR3C1), and other nuclear receptors such as the retinoic acid receptor (RAR, NR1B), retinoid $\mathrm{X}$ receptor ( $\mathrm{RXR}, \mathrm{NR} 2 \mathrm{~B}$ ), and peroxisome proliferators-activated receptor (PPAR, NR1C). Estrogens are small lipophilic molecules that traverse the cell membrane and bind to cytoplasmic ER $\alpha$ associated with chaperone proteins such as hsp90. Upon binding a cascade of events occur; the receptor dissociates from the chaperone proteins, dimerizes and associates with chromatin. ER $\alpha$ can either bind directly to DNA (classical pathway) or indirectly via protein-protein interactions (nonclassical pathway). In the classical pathway, ER $\alpha$ homodimers bind to a specific DNA sequence motif, the estrogen response element (ERE). The ERE is a $15 \mathrm{bp}$ palindrome consisting of two PuGGTCA half sites separated by a 3 bp spacer. ER $\alpha$ is also able to bind to imperfect EREs. Recent genomewide studies show that the ERE is the most predominant motif in ER $\alpha$-binding sites (Carroll et al. 2006, Lin et al. 2007, Welboren et al. 2009). In the nonclassical pathway, the ER $\alpha$ binds indirectly to the DNA via tethering to other transcription factors such as specificity protein 1 ( $\mathrm{Sp} 1)$, activating protein 1 (AP-1), or nuclear factor kappa b (NF- $\mathrm{B}$ ), and regulates transcription in an ERE-independent manner. The Sp1 family of transcriptional factors plays an important role in proliferation, differentiation, survival, and angiogenesis (Kaczynski et al. 2003, Safe \& Abdelrahim 2005). Sp1 can bind to GC-rich regions, which are present in many estradiol $\left(\mathrm{E}_{2}\right)$ responsive promoters. For example, mutational analysis revealed that the GC-rich region in the promoter of the transforming growth factor $\alpha$ (TGF $\alpha$ ) gene is required for $\mathrm{E}_{2}$-mediated gene activation (Vyhlidal et al. 2000). Several other genes have been identified that are activated by the ER/Sp1 pathway including e.g. the c-myc and progesterone receptor genes (Miller et al. 1996, Petz \& Nardulli 2000). The transcription factor AP-1 is a complex containing fos, jun, and other family members. Several $E_{2}$-regulated genes are dependent on AP-1, such as insulin-like growth factor I (IGF-I), ovalbumin, progesterone receptor, and pS2/TFF1 (Gaub et al. 1990, Savouret et al. 1994, Umayahara et al. 1994, Barkhem et al. 2002). The AP-1 complex binds to promoters of genes involved in growth, differentiation, and development. Many ER/AP-1responsive genes have been identified using microarray studies, indicating that $\mathrm{E}_{2}$-mediated regulation via the nonclassical pathway occurs frequently (DeNardo et al. 2005, Glidewell-Kenney et al. 2005). The NF- $\kappa \mathrm{B}$ family of transcriptional factors are involved in the immune and skeletal systems and inflammatory response (Kalaitzidis \& Gilmore 2005). NF- $\kappa$ B binds to $\kappa \mathrm{B}$ elements and regulates the expression of target genes. ER $\alpha$ has been shown to inhibit NF- $\kappa \mathrm{B}$ in an $\mathrm{E}_{2}$-dependent manner. The $\mathrm{ER} \alpha$ can directly inhibit the binding of NF- $\kappa$ B transcription factors to the DNA, but the mechanism is poorly understood.

\section{Target gene network}

\section{Single gene analysis}

To fully elucidate $E R \alpha$ function, the identification of its target gene network is essential. Many strategies have been employed to gain insights into the target gene network governed by the ER $\alpha$. Classically, target genes have been identified using 'single gene' experiments. The egg-white proteins in the chicken oviduct and the Xenopus laevis vitellogenin gene are among the first ER $\alpha$ target genes to be identified (Hayward et al. 1982, Lai et al. 1983, Chambon et al. 1984, Jost et al. 1984). Later, by comparing cDNA libraries of nontreated and $\mathrm{E}_{2}$-treated MCF-7 human breast cancer cells several other ER $\alpha$-responsive genes were identified such as the classical and intensively studied ER $\alpha$ target gene pS2/TFF1 (Brown et al. 1984, Jakowlew et al. 1984). ER $\alpha$-regulated genes identified using differential cloning are e.g. the cell cycle regulators c-myc and cyclin D1, connecting proliferation with $\mathrm{E}_{2}$ signaling (Dubik et al. 1987, Altucci et al. 1996).

\section{Estrogen response elements}

The first ERE was identified in 1986 in the promoter of the Xenopus vitellogenin gene. Transfection experiments showed that this element also functions in human cells, and that the core ERE could be defined as a $13 \mathrm{bp}$ palindrome (GGTCANNNTGACC; Klein-Hitpass et al. 1986). The availability of the entire human genome sequence allowed the computational search for EREs and ER $\alpha$ target genes. This approach led to the interesting observation that $\sim 70000$ EREs are present in the human genome, i.e. one in every $43 \mathrm{~kb}$ of DNA (Bourdeau et al. 2004). By comparing these with the merely 9944 EREs identified in the mouse genome, a total of 660 evolutionary conserved elements were found. The large number of EREs present in the genome and limited conservation between human and mouse indicates that a large fraction of the EREs may not be 'true' ER $\alpha$-binding sites. These in silico studies suggested that actual binding by ER $\alpha$ is dependent on more factors than just the DNA sequence. The hypothesis was put forward that the chromatin structure and hence the accessibility of binding sites plays a major role. Furthermore, the 
notion that sequence is not the only or decisive determinant in ER $\alpha$ binding is underscored by the observation that $\mathrm{ER} \alpha$ can bind indirectly via tethering to other transcription factors and subsequently regulate target genes in an ERE-independent manner.

\section{Expression profiling}

Microarrays, either cDNA or oligonucleotide, and serial analysis of gene expression are powerful tools that can be used to assess global changes in gene expression. Many gene expression profiling studies have been performed identifying $\mathrm{E}_{2}$-responsive genes, the number ranges from 100 to 500 (Charpentier et al. 2000, Coser et al. 2003, Frasor et al. 2003, Lin et al. 2004, 2007, Rae et al. 2005, Carroll et al. 2006, Kininis et al. 2007, Kwon et al. 2007, Stender et al. 2007). The large quantitative and qualitative differences between the various profiling studies are most probably due to the use of different cell lines, treatment times, platforms, and analysis methods. Collectively, expression profiles show that $\mathrm{E}_{2}$ activates as well as represses a large variety of targets including genes involved in cell cycle regulation and proliferation (e.g. cyclin D1 and cyclin G2), apoptosis (bcl-2 and survivin), and transcriptional regulation (c-fos and c-jun). Upregulated genes include among others activators of proliferation and downregulated genes include negative proliferation regulators.

Frasor et al. (2003) observed that at early time points following $E_{2}$ induction a greater proportion of genes are upregulated, while at later time points more genes are downregulated. This was also observed by Carroll et al. (2006), who postulated that early ER $\alpha$-mediated downregulation may be due to squelching while the increase in the number of downregulated genes at later time points may depend on the upregulation of the corepressor nuclear receptor interacting protein 1 (NRIP1) which mediates the repression of ER $\alpha$ target genes.

The number of $\mathrm{E}_{2}$-responsive genes identified by these transcriptome studies differs significantly even though the majority were performed using the MCF-7 cell line. The platform and specific conditions used certainly will have contributed to these differences, but other factors may also play a role. First of all, the experimental or technical differences between the profiling studies such as platforms, ligand concentration, treatment time, and statistical thresholds used. Secondly, the biological differences, i.e. the handling of the cells and the differences between MCF-7 sublines. MCF-7 cells have been in culture for many decades and as a result the cell lines used in different laboratories may not be the same anymore. Differences in karyotype, hormone receptor content, and growth rate have been observed although morphologically the cells look(ed) identical (Osborne et al. 1987, Bahia et al. 2002, Burdall et al. 2003).

It is important to note that a disadvantage of expression profiling is that indirect effects that affect the mRNA level are also measured which could be a major source of the observed differences. Lin et al. used the translation inhibitor cyclohexamide combined with the ER $\alpha$ antagonist ICI 182,780 to show that only a relatively small number $(23 \%)$ of $\mathrm{E}_{2}$-responsive genes are actually direct targets. More recently changes in RNA polymerase II (RNAPII) occupancy over the gene body has been used as a direct measure of gene activity (Nielsen et al. 2008, Welboren et al. 2009). We have used this method to identify 596 genes directly responding to $1 \mathrm{~h}$ of $\mathrm{E}_{2}$ treatment (Nielsen et al. 2008, Welboren et al. 2009). Profiling RNAPII occupancy has the advantage that direct effects on target genes are observed, whereas transcriptome profiling is the sum of changes in transcriptional activity and regulation at mRNA level as observed by mRNA profiling. Both methods are complementary.

\section{ChIP analysis}

ChIP assesses the binding of chromatin interacting proteins such as a transcription factors, cofactors, or histone modifications at a specific genomic position in living cells. Proteins and DNA are cross-linked with formaldehyde and the chromatin is fragmented by sonication. The protein of interest is precipitated using a specific antibody and the DNA to which it is bound is co-precipitated. In both the input and the precipitated fraction the relative concentration of specific DNA fragments is determined by qPCR and from this the occupancy of the protein of interest at any specific locus can be calculated. ChIP thus allows the identification of transcription- and cofactor recruitment to a specific locus upon ligand induction, as well as the order of recruitment. Furthermore, specific histone modifications present at a locus can be measured by ChIP, providing information on the local chromatin structure and epigenetic state. Shang et al. (2000) conducted early ER $\alpha$ ChIP experiments assessing ER $\alpha$ and cofactor occupancy at the cathepsin D (CATD), c-Myc, and pS2/TFF1 gene over time. They observed a stepwise recruitment of cofactors and found that the $\mathrm{ER} \alpha$ transcriptional complex repeatedly cycled on and off promoters. Métivier et al. (2003) used ChIP to extensively analyze the occupancy of a large panel of transcription factors and histone modifications at the $\mathrm{pS} 2 / \mathrm{TFF} 1$ promoter over time at $5 \mathrm{~min}$ intervals. 
A cyclic recruitment of cofactors, histone modifications, histone acetyl transferases (HAT), histone methyl transferases, and chromatin remodelers was observed. The authors concluded that ER $\alpha$-mediated transcription occurs in 'waves' that allow the cell to respond to environmental and others cues by continuously adjusting the rate of transcription of a gene.

\section{ChIP-chip}

Single ChIP, using sequence-specific primer sets combined with qPCR, is obviously not suited to gain genome-wide insight into transcriptional factor binding or histone modifications. By combining ChIP with microarray platforms (ChIP-chip), binding sites can be identified at a much broader scale. In ChIP-chip, the precipitated DNA is amplified, fluorescently labeled, and directly hybridized to a microarray or mixed with differential labeled input DNA. Initially, promoter arrays were used that contain the upstream regions of known genes including $\mathrm{CpG}$ islands that are often overlapping with promoter regions. These custom arrays have been used successfully by several laboratories resulting in the identification of many ER $\alpha$-binding sites and in some cases histone modifications or cofactor occupancy (Jin et al. 2004, Laganière et al. 2005, Cheng et al. 2006, Kininis et al. 2007, Kwon et al. 2007). Microarrays comprising the entire nonrepetitive human genome enabled a true genome-wide identification of ER $\alpha$-binding sites. The first study has been performed on Affymetrix arrays covering chromosome 21 and 22, and resulting in the identification of $57 \mathrm{ER} \alpha$-binding sites (Carroll et al. 2005). The majority of these sites turned out to be located in introns or distal to genes and only a small percentage were located in promoter regions. The authors showed that the distal ER $\alpha$-binding sites functioned as enhancers as demonstrated for the pS2/TFF1 gene and that the enhancer interacted with the promoter via looping. Sequence analysis of the ER $\alpha$-binding sites also revealed an enrichment of the FOXA1 motif and it was postulated that FOXA1 might act as pioneering factor that facilitates ER $\alpha$ binding. More recently, the same investigators published a genome-wide ER $\alpha$ and RNA polymerase II (RNAPII) ChIP-chip analysis using Affymetrix arrays identifying $3665 \mathrm{ER} \alpha$ and 3629 RNAPII-binding sites (Carroll et al. 2006). Re-analysis of the ER $\alpha$ ChIP-chip data revealed that the number of ER $\alpha$ sites was as high as 5782 (Lupien et al. 2008). As observed for chromosome 21 and 22, the number of ER $\alpha$ sites that is located in promoter regions is as low as $4 \%$. Sequence analysis of all binding sites revealed several enriched motifs and showed that the co-occurrence of the ERE and the AP-1 motif is negatively correlated, suggesting the AP-1 and ERE motif occur mutually exclusive while the Oct, FOXA1, and C/EBP motif are positively correlated. In addition, a role for the nuclear receptor corepressor NRIP1 in ER $\alpha$-mediated repression was reported.

In a later study, the ER $\alpha$ ChIP-chip experiment was repeated and 8525 sites were identified, of which $86 \%$ overlapped with the dataset that was previously published (Hurtado et al. 2008). A newly identified site was present in the ERBB2 gene. Tamoxifen resistant tumors have increased ERBB2 expression levels and cell lines overexpressing ERBB2 acquire resistance to tamoxifen. Binding site sequence analysis showed an enrichment of the PAX transcription factor binding motif. PAX2 is expressed in a subset of breast tumors and is regulated by tamoxifen in endometrial cancer cells. ChIP-qPCR showed that PAX2 was recruited to ER $\alpha$-binding sites upon tamoxifen but not upon $\mathrm{E}_{2}$ treatment. However, PAX2 recruitment to the ERBB2 gene was observed in the presence of tamoxifen as well as $E_{2}$. Furthermore, the authors show that PAX2 competes with the co-activator AIB-1 for binding at the ERBB2 gene. Increasing levels of AIB-1 block PAX2 binding and result in upregulation of ERBB2 and subsequent cell proliferation, reversing the antiproliferative effects of tamoxifen. Interestingly, in tamoxifen resistant cells PAX2 levels are decreased, resulting in increased expression of ERBB2. Reintroduction of PAX2 restored the ability of tamoxifen to inhibit cell growth indicating PAX2 is an important factor in mediating selective ER modulator (SERM) action.

A more recent ChIP-chip paper investigated the tissue-specific behavior of estrogens. Krum et al. (2008) compared the expression and ER $\alpha$-binding site profile in the breast cancer cell line MCF-7 with that of exogenous ER $\alpha$ in the U2OS osteosarcoma cell line to determine how estrogens exert this tissue specificity. Strikingly, $<10 \%$ of the genes responding to $\mathrm{E}_{2}$ in MCF-7 are responsive in U2OS cells. Furthermore, ChIP-chip analysis on chr1 and chr6 showed that less than $15 \%$ of the ER $\alpha$-binding sites were common between both cell types. To unravel the cell type-specific-binding of $\mathrm{ER} \alpha$, the presence of specific chromatin modifications at putative enhancers was determined. The authors showed that before $E_{2}$ treatment some enhancers contained the active mark $\mathrm{H} 3 \mathrm{~K} 4 \mathrm{me} 2$ while others contained the heterochromatic mark $\mathrm{K} 3 \mathrm{~K} 9 \mathrm{me} 2$, and that these marks correlated with the binding of ER $\alpha$. Interestingly, FOXA1 does not seem to play a role in the U2OS cells. 
ChIP-chip has also been used to assess the effect of post-translational modifications of $\mathrm{ER} \alpha$ on genomewide binding and target gene profile (Bhat-Nakshatri et al.2008). The authors focused on the serine/threonine kinase AKT and compared ER $\alpha$ binding in parental MCF-7 cells with AKT overexpressing MCF-7 cells. More than half of the ER $\alpha$-binding sites are present in both datasets and gene expression profiling showed that AKT increased the number of $E_{2}$ responsive genes from 833 to 1063. Analysis of the target genes revealed that AKT induces changes in the TGF- $\beta$, NF- $\kappa \mathrm{B} / \mathrm{TNF}$, RA, and E2F pathways. Besides directly influencing $\mathrm{ER} \alpha$ binding, AKT also induces secondary effects due to changes in the expression of E2F2 and E2F6, which subsequently change the expression of estrogen-induced or estrogen-repressed secondary target genes either in the presence (E2F6) or absence of $\mathrm{E}_{2}$ (E2F2). In conclusion, the authors postulate that AKT alters $\mathrm{ER} \alpha$ and/or coactivatorbinding resulting in changes in binding occupancy and target gene expression.

Liu et al. (2008) compared the binding of ER $\alpha$ and ER $\beta$ using ChIP-chip and an inducible ER $\beta$ system. Although there was a high degree of overlap between both profiles, a group of sites showed selective binding by either $E R \alpha$ or $E R \beta$. Interestingly, ER $\beta$-binding sites were located closer to the transcription start site compared to ER $\alpha$. In addition, ER $\beta$-binding site sequences included CG-rich motifs, while ER $\alpha$ sites were enriched for TA-rich motifs. Together these differences could explain the different expression profile of $\mathrm{ER} \alpha$ and $\mathrm{ER} \beta$ (Liu et al. 2008).

\section{ChIP-deep sequencing}

With next generation high throughput sequencing platforms millions of fragments can be sequenced simultaneously. DNA fragments can be identified at significantly decreased costs and with much higher sensitivity, resolution, and accuracy as compared to microarrays. Lin et al. used a ChIP-paired end diTag cloning and sequencing strategy (ChIP-PET) to map ER $\alpha$-binding sites. A total of 635371 tags have been sequenced (454 platform), of which 361241 (57\%) could be unambiguously mapped to the human genome. In total, 1234 high-confidence ER $\alpha$-binding sites were identified. Of these, $71 \%$ contained an ERElike sequence and many other transcription factor motifs were enriched, including Sp1, AP-1, and FOXA1. Illumina high throughput sequencing has also been successfully combined with ChIP for the identification of precipitated fragments. Recently, we identified $10205 \mathrm{ER} \alpha$-binding sites in MCF-7 cells using ChIP-Seq and assessed the effect of tamoxifen and fulvestrant on $\mathrm{ER} \alpha$ binding. Fulvestrant is a full $\mathrm{E}_{2}$ antagonist that increases $\mathrm{ER} \alpha$ protein turnover and results in degradation of $E R \alpha$, although at the $1 \mathrm{~h}$ timepoint no degradation was observed. We showed that both tamoxifen as well as fulvestrant affect but do not abolish ER $\alpha$ binding (Welboren et al. 2009). Also, the effect of different ligands on the RNAPII occupancy over target genes was investigated using ChIP-Seq. Upon $\mathrm{E}_{2}$ treatment, 596 genes show changes in RNAPII occupancy. Tamoxifen and fulvestrant treatment abolished RNAPII occupancy over $E_{2}$-upregulated target genes. On $E_{2}$-repressed genes tamoxifen acts as an agonist, downregulating these genes while fulvestrant antagonizes the $\mathrm{E}_{2}$-induced repression and often increases the RNAPII occupancy. Thus, both antagonists act differentially on $\mathrm{E}_{2}$-induced and $\mathrm{E}_{2}$-repressed genes.

\section{Comparison of ChIP-profiles}

Different ER $\alpha$ ChIP-profiling studies, i.e. ChIP-chip, ChIP-PET, and ChIP-Seq, have identified a multitude of ER $\alpha$ interaction sites. However, the number of sites detected in each study is significantly different and the profiles show a limited overlap, even though all studies used the MCF-7 breast cancer cell line and performed a similar $\mathrm{E}_{2}$ treatment.

Clearly, ChIP profiling is a relatively new development and it is likely that as the approach matures the variation between experiments and laboratories will disappear over time. In this light, the transition from microarray to sequencing-based detection of ChIP DNA fragments seems to be an important step in that direction.

Comparing the existing ChIP-chip and ChIP-Seq $\mathrm{ER} \alpha$ sets shows that around half of the binding sites overlap and that both sets contain a considerable number of specific sites. Both sequence-based profiles (ChIP-Seq and ChIP-PET) show a larger overlap, although one has to keep in mind that the ChIP-PET set is much smaller (Fig. 1). One obvious factor that will certainly contribute but is unlikely to be the main course is the biological variation in the MCF-7 (sub)lines used and/or handling of the cells.

One of the main differences between these profiles, however, is that different antibodies against the ER $\alpha$ were used, which is likely to affect the ChIP and thus the ER $\alpha$-binding profiles. Different antibodies, or even antibody batches, will have different specificities and avidities for the target protein. Antibodies raised against different peptides will recognize different epitopes. As a consequence, epitope masking due to 


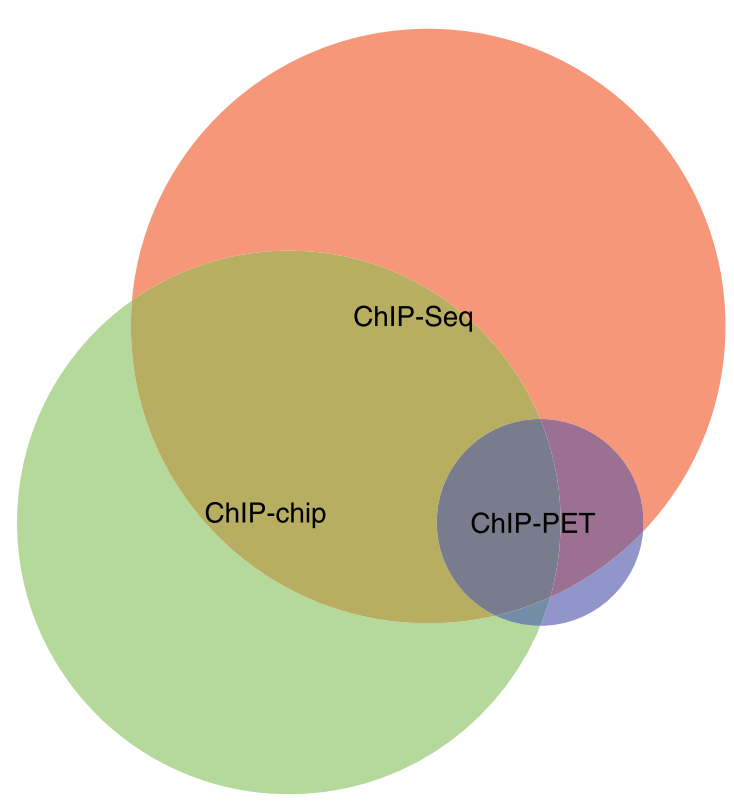

Figure 1 Comparison of the ChIP-Seq (10 205), ChIP-chip (8525), and ChIP-PET (1234) ER $\alpha$-binding site profile. The ChIP-Seq data is compared with the new ChIP-chip data from Carroll et al. (Hurtado et al. 2008) and the ChIP profile from Lin et al. The overlap between all profiles is limited.

conformational shielding or binding and cross-linking of an interactor may block or hinder the binding of some but not other antibodies. For polyclonal antibodies, epitope masking is less likely to affect the outcome as multiple epitopes can be recognized. On the downside, polyclonal antibodies may display more cross-reactivity.

Another factor contributing to the differences in ER $\alpha$-binding profile is the platform used to identify the precipitated DNA fragments. Microarray based detection has been widely used and provides the first genome-wide views of transcriptional factor binding and histone modifications. However, microarray approaches do have intrinsic disadvantages related to the sequence composition of probes, differences in melting temperature, annealing efficiency, and crosshybridization which are discussed in detail elsewhere (Buck \& Lieb 2004, Hanlon \& Lieb 2004, Bulyk 2006, Wu et al. 2006, Gräf et al. 2007). ChIP-Seq, in which co-precipitated fragments are identified by high throughput sequencing have important advantages over microarrays. First, ChIP-Seq is unbiased and enables a higher resolution and accuracy. Furthermore, the fabulous sequencing depth allows the identification of binding sites that are moderately enriched, that probably would not have escaped detection using an array approach. Because sequencing-based methods are not dependent on hybridization the 'background' is significantly lower when compared to microarrays. An additional important advantage of ChIP-Seq is that information on repetitive sequences can be obtained which is not possible on microarrays, because these contain only nonrepetitive regions (Marks et al. 2009).

Notwithstanding the differences, the combined ER $\alpha$-binding site profiles identify a large number of stable, high-affinity ER $\alpha$ interaction sites and a set of more transient ER $\alpha$ interaction sites. High affinity sites are more likely to be detected by all techniques, while lower affinity sites may only be detected when using the more sensitive and accurate sequencing-based approaches, i.e. ChIP-Seq.

Collectively, ChIP profiling studies have revealed that the number of ER $\alpha$ interaction sites is much larger than the number of $E_{2}$-responsive genes hitherto identified by gene expression profiling. The biological implications of the discrepancy remain as one of the questions to be answered. One assumption is that a large number of ER $\alpha$-binding sites may not be functional, i.e. ER $\alpha$ binding has no consequence on the transcription of closely positioned genes in the particular cell investigated. It is likely that conditions for transcriptional regulation at these sites are not favorable, i.e. cofactors or transcription factors are not co-recruited or a specific post-translational modification of the chromatin is absent and hence the level of transcription from the gene is not affected. An alternative hypothesis is that multiple $\operatorname{ER} \alpha$ sites cooperate and interact via looping to regulate expression of one or more target genes. More research is necessary to elucidate this aspect of ER $\alpha$-mediated regulation. A recently developed technique, chromatin interaction analysis using paired-end tag sequencing (ChIA-PET), may shed light on this issue (Fullwood \& Ruan 2009).

\section{Cofactor choice}

$\mathrm{ER} \alpha$ mediated gene regulation is controlled by the interplay of ligand, receptor, DNA (ERE), and cofactors. Cofactors interact with the receptor in a ligand-dependent manner and are often part of large multiprotein complexes that regulate transcription by recruiting components of the basal transcription machinery, regulating chromatin structure and/or modifying histones (reviewed by Klinge 2000). Coactivators are required for transcriptional activation, while corepressors decrease the transcriptional activity. The presence and levels of cofactors will, to a large part, determine the transcriptional outcome and 
are vital in ER $\alpha$-mediated regulation. Protein-protein interaction studies have revealed a multitude of nuclear receptor cofactors.

The best characterized are the p160 family of steroid receptor cofactors; steroid receptor coactivator 1 (SRC-1), SRC-2 (TIF2/GRIP1), and SRC-3 (AIB1/RAC3/ACTR). An increase in the level of SRC-3/AIB1 has been observed in breast and prostate tumors (Anzick et al. 1997, Gnanapragasam et al. 2001). A limited number of SRC-binding sites have been identified using a ChIP-cloning approach (Labhart et al. 2005) while most recently ChIP-chip has been used (Kininis et al. 2007). Both studies show that the binding of SRC cofactors correlated very well with ER $\alpha$ binding. The p160 family and many other nuclear receptor cofactors contain an LXXLL (NR-box) motif, which facilitates the interaction of the cofactor with the AF-2 domain of the ER $\alpha$. One function of these cofactors is to recruit other proteins such as CREB-binding protein (CBP)/p300 and pCAF that have HAT activity. The CBP is a not only a coactivator of ER $\alpha$ but also of other nuclear receptors and many other transcription factors such as p53 and NF-кB (Chakravarti et al. 1996, Kamei et al. 1996, Avantaggiati et al. 1997, Perkins et al. 1997, Frønsdal et al. 1998). p300 shares many functional properties with CBP, nevertheless, CBP and p300 are not completely redundant as shown by targeted deletion studies (Yao et al. 1998). Another group of factors recruited by the p160 family are the protein arginine methyl transferase (PRMT) family of proteins that are able to methylate histone $\mathrm{H} 3$ and H4. The first PRMT family member to be discovered, coactivator associated arginine methyltransferase 1 (CARM1), or PRMT4; Chen et al. 1999), enhances ER $\alpha$-mediated transcriptional activity by interacting with GRIP1, a p160 family cofactor and p300 (Chen et al. 2000). CARM1 methylates several arginines in histone 3, i.e. H3R2, H3R17 and H3R26, upon nuclear receptormediated activation (Ma et al. 2001, Schurter et al. 2001). Another family member, PRMT1, methylates H4R3, which in turn facilitates the acetylation of $\mathrm{H} 4$ by p300 (Wang et al. 2001). PRMT1 is an essential cofactor for $\mathrm{ER} \alpha$-mediated $\mathrm{pS} 2 / \mathrm{TFF} 1$ regulation (Wagner et al. 2006). Yeast two-hybrid studies have shown that PRMT2 can also interact with the ER $\alpha$ and that it enhances $E R \alpha$ transcriptional activity upon ligand binding (Qi et al. 2002). Other cofactors that possess chromatin remodeling activity are for example Brahma (BRM) and Brahma related gene-1 (BRG-1). They are subunits of an ATP-dependent chromatin remodeling complex and are recruited to $\mathrm{E}_{2}$ responsive promoters upon induction (DiRenzo et al. 2000,
Belandia et al. 2002). These remodelers alter the local chromatin structure to a more open conformation, permitting transcription as is elegantly shown for GR (John et al. 2008).

Nuclear receptors that bind DNA in the absence of ligand, antagonist loaded receptors or receptors causing gene repression interact with corepressors proteins such as nuclear receptor corepressor ( $\mathrm{NCoR})$ and silencing mediator of retinoid and thyroid hormone receptors (SMRT). Corepressors interact with helix 3 and 5 of the ER $\alpha$ via so called CoRNR boxes (LXXI/HIXXXI/L) (Hu \& Lazar 1999). NCoR and SMRT in turn recruit large repressor complexes including histone deacetylases (HDAC) that repress gene activity by maintaining or reinforcing a repressive chromatin state. Antagonist loaded ER $\alpha$ does bind regulatory regions (Welboren et al. 2009) and recruits corepressor complexes, as shown for the $\mathrm{pS} 2 / \mathrm{TFF} 1$ and c-myc genes where NCoR, HDAC3 and the nucleosome remodeling complex NURD are recruited, leading to a repressive chromatin state (Liu \& Bagchi 2004). Low levels of NCoR expression have been shown to have a predictive value in tamoxifen resistance and NCoR levels decrease during progression of breast cancer (Kurebayashi et al. 2000, Girault et al. 2003). Another factor involved in ER $\alpha$-mediated regulation is the histone demethylase LSD1. Using ChIP-DSL Garcia-Bassets et al. (2007) showed that LSD1 is recruited to a subset of $E_{2}$-responsive genes upon treatment and subsequently demethylates $\mathrm{H} 3 \mathrm{~K} 9$, hence counteracting the repressive effect of methylation.

To gain insight into cofactor choice on ER $\alpha$ mediated regulation genome-wide cofactor profiling will be essential. Hitherto, data obtained at a single gene level has been reported and has been extrapolated to hold true for all or a large number of similarly regulated genes. Genome-wide profiling of nuclear receptor cofactors will show whether or not the model of regulation that was determined on single or at best a handful of genes does apply genome-wide.

\section{Epigenetic marks}

Genome-wide epigenetic profiling studies have revealed that the chromatin structure and epigenetic marking of a promoter, enhancer, and coding body of a gene correlates with the transcriptional state. Epigenetic marks consist of covalent post-translational modifications of N-terminal histone tails (Roh et al. 2004, Schübeler et al. 2004, Bernstein et al. 2005, Pokholok et al. 2005, Barski et al. 2007). Epigenetic marks such as acetylation, phosphorylation, methylation, and ubiquitination are deposited and removed by 
coregulatory complexes in a serial and combinatorial manner. Modification of histone tails results in dynamic changes in the chromatin structure and restrict or permit binding of transcription factors (Jenuwein \& Allis 2001, Rosenfeld et al. 2006). Several studies have been performed investigating the role of epigenetics in ER $\alpha$-mediated regulation. Bauer et al. (2002) showed that the arginine methyltransferase CARM1 is recruited to the $\mathrm{pS} 2 / \mathrm{TFF} 1$ promoter upon $\mathrm{E}_{2}$ induction, and that this event correlates with the methylation of arginine 17 of histone $\mathrm{H} 3$ and transcriptional activation. Kwon et al. (2007) profiled ER $\alpha$ binding, histone methylation, and acetylation. Histone H3K9 acetylation, which is associated with an open chromatin structure and increased transcriptional output, was observed at the promoters and enhancers of the active pS2/TFF1 and GREB1 gene. In addition, the promoter regions contained $\mathrm{H} 3 \mathrm{~K} 4$ tri-methylation, a mark that is widely associated with active promoter regions. H3K4 mono-methylation was associated with active genes, while $\mathrm{H} 3 \mathrm{~K} 4$ di-methylation was observed primarily on the promoters of active genes and to a lesser extent on enhancers. Both H3K27 di- and tri-methylation showed distinct patterns over the GREB1 and pS2/TFF1 gene (Kwon et al. 2007). Kininis et al. (2007) assessed histone $\mathrm{H} 3$ and $\mathrm{H} 4$ acetylation using a custom promoter array and revealed a correlation between histone acetylation and RNAPII occupancy, reinforcing the notion that histone acetylation correlates with gene activity. Métivier et al. (2003) performed a detailed time-course analysis of the pS2/TFF1 promoter and showed that $\mathrm{H} 3$ and $\mathrm{H} 4$ acetylation and di-methylation are deposited and removed in a cyclical fashion. The recruitment of cofactors, ER $\alpha$, and RNAPII also occurred in a cyclical manner, producing transcriptional 'waves'. Interestingly, two recent publications showed that besides histone modifications DNA methylation also takes place in a cyclical fashion at the pS2/TFF1 promoter (Kangaspeska et al. 2008, Métivier et al. 2008). The authors observed DNA methylation at the end of each productive transcription cycle. DNA methylation correlated with the occurrence of the methylated $\mathrm{CpG}$-binding proteins $\mathrm{MeCP} 2$, DNMT3a/b, DNMT1 and the chromatin remodeler SWI/SNF. Furthermore, the authors suggest that DNMT3a/b is involved in both methylation and demethylation of the promoter. These data suggest that both histone modifications and DNA methylation may be intricate parts of the 'normal' transcriptional cycle.

Histone methylation has been reported to prevent gene activation by unliganded receptors (GarciaBassets et al. 2007). Using ChIP-DSL and a promoter array the authors show that the histone demethylase
LSD1 is recruited to a subset of ER $\alpha$ target genes upon $\mathrm{E}_{2}$ treatment. In the absence of ligand these genes show H3K9 methylation. The H3K9 methylation prevents the effective binding of unliganded ER $\alpha$. The binding of liganded ER $\alpha$ permits LSD1 recruitment and the removal of the inhibitory marks allowing transcription to occur. Most current models on ER $\alpha$-mediated regulation, however, are based on analysis of single genes and the question arises as to whether these reported deposition of marks and the inferred mechanisms are the rule or the exception in regulation by $\mathrm{ER} \alpha$.

Yet another intriguing layer of complexity to ER $\alpha$ target gene regulation has been recently reported. The occurrence of controlled and local DNA damage and repair has been shown to play a role in the ER $\alpha$-mediated regulation of bcl-2 (Perillo et al. 2008). $\mathrm{E}_{2}$ treatment results in the demethylation of $\mathrm{H} 3 \mathrm{~K} 9$ by LSD1, methylation of H3K4 and the formation of a loop between the enhancer and promoter of bcl-2. Demethylation of lysine H3K9, in this case by LSD1, is an oxidative process that produces $\mathrm{H}_{2} \mathrm{O}_{2} \cdot \mathrm{H}_{2} \mathrm{O}_{2}$ causes local DNA damage by formation of 8-oxo-guanine. The 8-oxo-guanine is removed via base excision repair by 8-oxo-guanin DNA glycosylase 1 (OGG1). In addition, topoisomerase II $\beta$, which is capable of repairing single stranded breaks in double-stranded DNA, is also recruited. These data show that local DNA damage and repair induced by $E_{2}$-dependent demethylation of H3K9 may also play an important role in ER $\alpha$ signaling. Double strand DNA breaks, induced by topoisomerase II $\beta$, have been previously reported in the regulation of transcription of the pS2/TFF1 gene ( $\mathrm{Ju}$ et al. 2006). The question is whether transient DNA breaks and the DNA repair machinery plays a general role in transcriptional regulation. The plethora of post-translational modifications, the vast number of histone modifying enzymes and the serial and combinatorial fashion in which these modifications are applied, points to a very complex process to ensure timely and tight regulation.

\section{Looping}

Genome-wide ER $\alpha$ ChIP profiling studies hitherto revealed that only a minor fraction of ER $\alpha$-binding sites are located in promoter regions and that the vast majority are located at great distances $(>20 \mathrm{~kb})$ from genes (Carroll et al. 2006, Lin et al. 2007, Welboren et al. 2009). Because of these large distances to genes, assignment of binding sites to target genes is often rather arbitrary. Moreover, the number of identified $\mathrm{ER} \alpha$-binding sites is much larger than the number of 
$\mathrm{E}_{2}$-regulated genes identified by expression or RNAPII profiling, indicating that many binding sites are idle or that multiple ER $\alpha$-binding sites cooperate to regulate transcription. Using $3 \mathrm{C}$ it has been shown that at the classical ER $\alpha$ target genes pS2/TFF1, GREB1, and bcl-2, multiple ER $\alpha$-binding sites interact via looping to regulate transcription (Carroll et al. 2005, Deschênes et al. 2007, Perillo et al. 2008). Pan et al. (2008) further investigated the interaction between the TFF1 promoter region and the upstream enhancer. They show that both the enhancer and the promoter region are occupied by the same suite of transcription factors consisting of ER $\alpha$, cofactors and RNAPII. Furthermore, the promoter and upstream enhancer interact via looping in an $\mathrm{E}_{2}$-dependent manner and the transcriptional output of the interaction is dependent on the ERE sequence.

Long-range chromosomal interactions are probably a general mechanism in transcriptional communication and regulation by $\mathrm{ER} \alpha$ and many other transcription factors. Recently, a combination of 3C with ChIP-DSL, the 3D assay (deconvolution of DNA interactions by DSL), was used to identify regions that interact with the enhancer of the TFF1 gene on a genome wide scale (Hu et al. 2008). Strikingly, the GREB1 promoter and enhancer on chr2 interacted with the TFF1 enhancer on chr21. Subsequent FISH analysis showed that indeed both loci interacted upon $\mathrm{E}_{2}$ induction. The knockdown of $\mathrm{CBP} / \mathrm{p} 300$ or SRC1 abolished the GREB1:TFF1 interaction. Furthermore, inhibition or knockdown of nuclear myosin-I abolished the interaction, as did the knockdown of dynein light chain-1 and the chromatin remodeler BAF53. The histone demethylase LSD1 has previously been shown to be essential for $\mathrm{E}_{2}$ mediated regulation. Interestingly, LSD1 knockdown had little effect on interchromosomal interaction of GREB1:TFF1. Furthermore, FISH analysis showed that the sites of the interchromosomal interactions are spatially related to nuclear speckles, regions that are enriched for key transcriptional elongation factors, chromatin remodelers, and splicing factors. LSD1 knockdown prevented the interaction of the GREB1:TFF1 loci with these nuclear speckles. Liganded $\mathrm{ER} \alpha$ thus initiates interchromosomal interactions that are important for enhancement of ligand-dependent transcription (Hu et al. 2008).

High throughput alternatives of the $3 \mathrm{C}$ method have been developed to study interactions on a genomewide scale. Circular chromosome conformation capture (4C) identified more than a hundred regions that interacted with the H19 imprinting control region (Zhao et al. 2006). An alternative high throughput technique named carbon copy chromosome conformation capture (5C) has been used to identify looping in the $\beta$-globin locus (Dostie et al. 2006). More recently a new approach has been announced, ChIAPET (Fullwood \& Ruan 2009). Using this technique all chromatin interactions can be detected in one experiment. In ChIA-PET, chromatin is crosslinked and sheared in small fragments. A linker sequence is introduced in the junction of two DNA fragments that are in close proximity due to chromatin interaction. The linker-connected ligation products are subsequently extracted and sequenced. Mapping the two paired fragments onto the genome reveals the interacting regions.

Applying these technologies to ER $\alpha$ will enable the detection of 'all' chromatin interactions taking place upon ligand or antagonist binding and may shed light on the difference in the number of ER $\alpha$-binding sites and number of genes changing upon $\mathrm{E}_{2}$ treatment.

\section{FOXA1}

Recently, the forkhead box protein FOXA1 was identified as a factor intimately associated with ER $\alpha$ mediated transcriptional regulation. The FOXA1 motif was found to be highly enriched in ER $\alpha$-binding sites (Carroll et al. 2005, 2006, Laganière et al. 2005). ChIP-chip of FOXA1 showed that $50-60 \%$ of the FOXA1-binding sites overlap with ER $\alpha$-binding sites. The authors postulated that FOXA1 acts as a pioneering factor that binds $\mathrm{H} 3 \mathrm{~K} 4 \mathrm{me} 1 / 2$-rich and $\mathrm{H} 3 \mathrm{~K} 9 \mathrm{me} 2$-poor regions and facilitates $\mathrm{ER} \alpha$ binding (Lupien et al. 2008). ER $\alpha$ ChIP-Seq data from our laboratory, however, shows that only a small number of ER $\alpha$-binding sites (7\%) contain the FOXA1 motif (Welboren et al. 2009). In addition, in the ChIP-DSL study by Kwon et al. no significant association of ER $\alpha$ binding sites and the FOXA1 motif was observed. However, only promoter regions were assessed by ChIP-DSL, which could contribute to the lack of FOXA1 enrichment because only a relatively small fraction of ER $\alpha$-binding sites are located in promoter regions (Kwon et al. 2007). Taken together the question remains to what extent FOXA1 plays a role in $\mathrm{ER} \alpha$-mediated regulation.

\section{ER $\alpha$ antagonists}

The growth of many breast tumors is $\mathrm{E}_{2}$ dependent, and hence blocking $E_{2}$ binding to $E R \alpha$ by antagonists is used as a therapeutic treatment. The successful application of tamoxifen has triggered vivid interest in the development of many (partial) antagonists, so called SERMS. SERMs bind in the same pocket as $\mathrm{E}_{2}$, but the compound loaded ER $\alpha$ ligand binding domain 
adopts a different conformation. The crystal structure of the compound loaded ligand-binding domain has been solved and shows that binding of an antagonist elicits a re-positioning of helix 12 that prevents/ disrupts the transcriptional activity of AF-2 and inhibits interaction with coactivators (Brzozowski et al. 1997). SERMs operate either as agonist, antagonist or mixed agonist/antagonist based on a set of variables such as type of drug or target tissue. The transcriptional outcome of SERM loaded ER $\alpha$ is mostly determined by the conformation of ER $\alpha$ upon ligand binding, the presence or absence of coregulatory proteins and the effector site/promoter. The most successful and widely used SERM is tamoxifen, which is applied in the clinic for the treatment and prevention of breast cancer. Notwithstanding its great beneficial effects, tamoxifen has some disadvantages, namely induction of resistance. Tamoxifen resistance will eventually occur in all cases of advanced breast cancer and enables the tumor to grow in the presence of tamoxifen. The mechanism by which this occurs is still not clear; it has been reported that growth factor signaling might play an important role. Changes in the levels of epidermal growth factor receptor (EGFR), human EGFR type 2 (ERBB2/HER2) and IGF receptor type 1 (IGF-IR) and their downstream signaling pathways are associated with tamoxifen resistance (Massarweh et al. 2008). Recently, PAX2 has been shown to mediate repression of ERBB2 upon tamoxifen treatment, connecting ER $\alpha$ with the ERBB2 pathway (Hurtado et al. 2008). An additional disadvantage of tamoxifen is its tissue specific effect; tamoxifen acts as an antagonist in breast, but as an agonist in the uterus, resulting in an increased risk of endometrial cancer. The expression pattern and abundance of activated cofactors in the different tissues may very well determine the tissue specific effects of SERMs (Smith \& O'Malley 2004).

Interestingly, our recent ChIP-Seq data (Welboren et al. 2009) shows that tamoxifen induces ER $\alpha$ binding to a subset of the $E_{2}$-induced ER $\alpha$-binding sites, indicating that the DNA sequence or chromatin structures may in part determine the tamoxifen response. We have also shown that tamoxifen has a repressive effect on a large set of genes that appear not to respond to $E_{2}$. The observed repression by tamoxifen may therefore be independent of the presence of $\mathrm{ER} \alpha$ protein.

\section{ER $\alpha$ target genes and breast cancer}

Considerable effort has gone into gene expression profiling to diagnose, monitor and to predict disease progression and response to chemo- and endocrine therapy. Routine pathological tumor assessment of lymph node status, tumor size and histological tumor grade do not accurately predict the response to therapy or determine whether or not metastasis will occur. Based on histological and clinical guidelines, almost $90 \%$ of lymph node negative patients now receive systematic adjuvant treatment. The use of a tumor type specific molecular signature is generally seen as of great benefit to tailor treatment. Gene expression profiling studies have aided the selection of breast cancer patients that would not need adjuvant chemoand/or endocrine therapy (van't Veer et al. 2002). The gene expression signature predicts that $70-80 \%$ of these patients are unlikely to develop metastasis, so these patients are currently overtreated. Several other gene expression profiles predict recurrence and overall survival and/or tamoxifen resistance (Ma et al. 2004, Paik et al. 2004, Jansen et al. 2005, Wang et al. 2005, Frasor et al. 2006, Oh et al. 2006, Gräf et al. 2007, Chanrion et al. 2008, Kok et al. 2009, Lippman et al. 2008, Zhang et al. 2009).

Epigenetic silencing of loci is frequently observed in cancer. HDAC inhibitors can alleviate the epigenetic repression of genes and has been shown to inhibit cell growth and activate apoptosis in the MCF-7 breast cancer cell line, indicating that epigenetic silencing plays an important role in breast cancer (Pledgie-Tracy et al. 2007, Im et al. 2008). Alterations in the DNA methylation profile are observed in many cancers (Baylin 2005). Genome-wide profiling of DNA methylation, e.g. methylated DNA immunoprecipitation using a specific antibody (MeDIP) or methylated DNA precipitation using protein affinity columns (MethylCap), provides detailed information on the methylation state of loci and can identify epigenetically silenced loci (Wilson et al. 2006). So far, gene expression profiles are based on the expression level of a small group of genes. However, a wealth of information on $\mathrm{ER} \alpha$ regulation and the network of target genes governed by ER $\alpha$ have become available in recent times and await its translation into clinic applications. Furthermore, several genomic regions important for the development of breast cancer have been identified recently using genome-wide association studies (Ahmed et al. 2009, Thomas et al. 2009, Zheng et al. 2009). These regions identify new pathways contributing to the development of breast cancer and can be combined with profiling data. Gene expression profiling using high throughout sequencing of the transcriptome (RNA-Seq) has much improved sensitivity, resolution and accuracy. Sequencing of the transcriptome has the big advantage that mutations and translocations can be detected because the sequence of 
'each' transcript is determined. Furthermore, RNA-Seq is much more quantitative as compared to array based gene expression profiling, RNA-Seq can distinguish/ detect different isoforms and can determine transcript boundaries. In addition, tumor specific and driver mutations can be determined (Nagalakshmi et al. 2008, Sultan et al. 2008, Wilhelm et al. 2008). The ever increasing sequencing capacity and decreasing costs hold great promises for the application of RNA/ ChIP-Seq profiling to assist in diagnosis and prognosis. The presence or absence of genomic alterations such as copy number variation, inversions and deletions, the gene expression profile and the epigenetic state of loci are likely to be of high predictive value. Combined ChIP, epigenetic, RNA profiles or signatures and genome-wide association studies are likely to improve the monitoring of disease progression and may lead to a more tailored and personalized approach in endocrine treatment selection of breast cancer patients.

\section{Future directions and conclusions}

A comprehensive and detailed picture of ER $\alpha$ mediated transcriptional regulation is beginning to emerge (Fig. 2). Several regulatory and signaling pathways converge to ultimately regulate expression of an ER $\alpha$ target gene. Genome-wide ChIP and RNA profiling combined with deep sequencing has greatly increased our knowledge of the ER $\alpha$ target gene network. Hitherto the majority of data has been generated using one cell line and rather similar conditions. The effect of signaling pathways, the presence and levels of cofactors on the global target gene network can now be determined with relative 'ease'. In addition, the role of the ER $\alpha$ in different cell lines and tissues can be studied and most importantly, the application of the profiling approaches to tumors may provide the real in vivo picture. The sequencing of tumor genomic DNA and the determination of DNA methylation and RNA profile, as planned in the

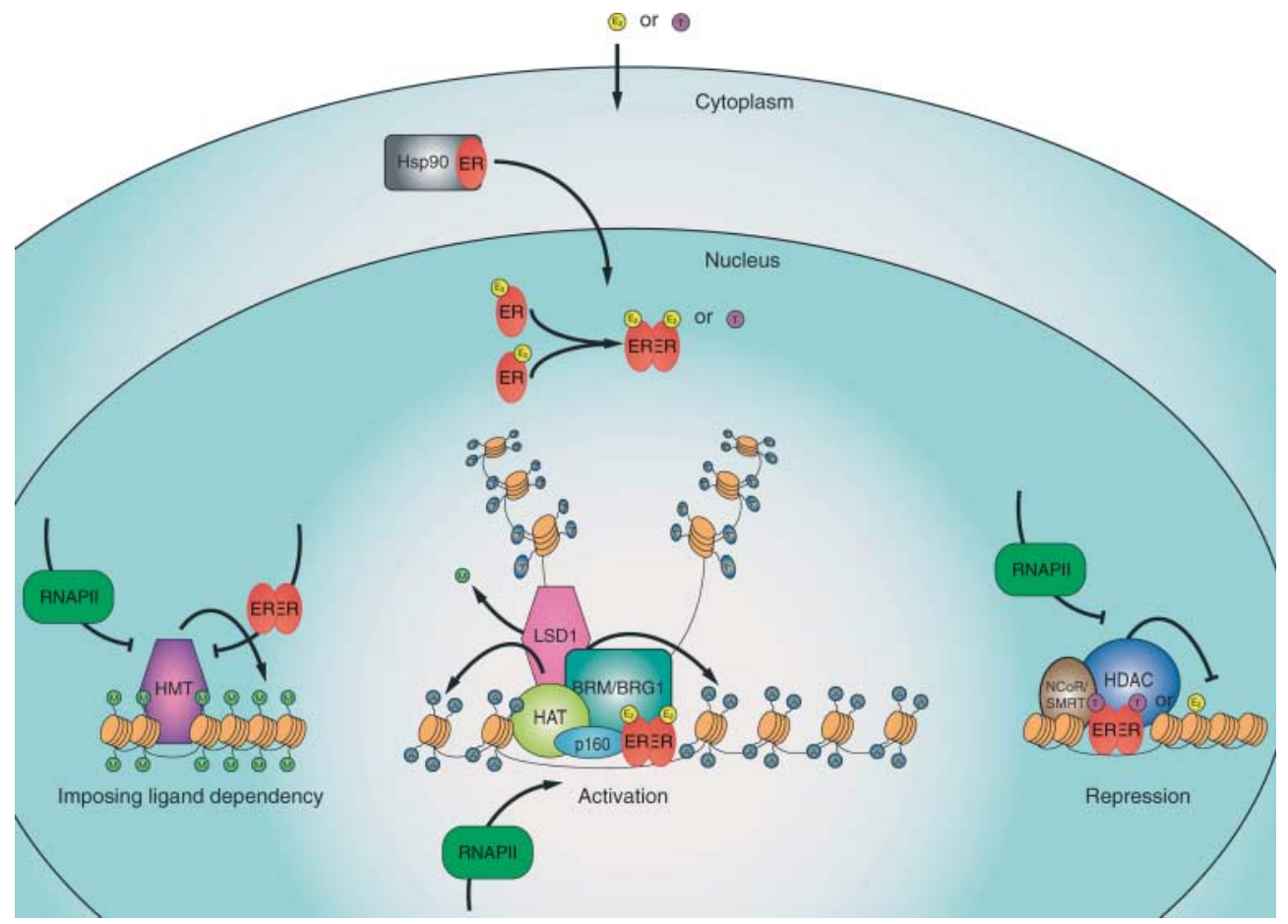

Figure 2 Overview of ER $\alpha$-mediated regulation of transcription. Activation of genes by an unliganded receptor is prevented due to methylation of histone tails by H3K9-specific histone methyl transferases. Ligand, e.g. estradiol $\left(\mathrm{E}_{2}\right)$ or the SERM tamoxifen, diffuses through the cellular membrane and binds cytoplasmic ER $\alpha$. Upon ligand binding ER $\alpha$ disassociates from chaperone proteins such as hsp90, translocates to the nucleus and dimerizes. The ER $\alpha$ binds chromatin and in a subset of genes recruits the histone demethylase LSD1. LSD1 removes the methyl mark that prevents gene activation by the unliganded receptor and also plays a role in the interaction of distal enhancer regions via looping. At upregulated genes, cofactors such as AIB1 (p160 family) are recruited and a complex containing histone acetyl transferase activity is assembled. The $\mathrm{N}$-terminal histone tails are acetylated, resulting in an open chromatin conformation. In addition, cofactors with nucleosome remodeling activity (BRG1/BRM) are recruited. Finally, RNA polymerase II and the general transcription machinery assemble at the promoter and the gene is transcribed. At repressed genes, either $E_{2}$-repressed genes or genes repressed upon tamoxifen treatment, the corepressors NCoR or SMRT are recruited and a histone deacetylase complex is assembled. Acetyl groups are removed from histone tails and the chromatin is in a closed conformation, which is not permissive for transcription to occur. 
International Cancer Genome Consortium (ICGC), will provide invaluable insight in tumor development and progression. With the decreasing cost, and increasing accuracy and capacity of high throughput sequencing platforms, the amount of data is explosively increasing. The expectation is that our understanding of ER $\alpha$-mediated regulation will greatly increase and will ultimately lead to new diagnostic/ prognostic tools, to therapeutic targets and a more tailored treatment. The integration of all this genomic data and its clinical application will be the challenge of the near future.

\section{Declaration of interest}

The authors declare that there is no conflict of interest that could be perceived as prejudicing the impartiality of the research reported.

\section{Funding}

This work was supported in part by the Radboud University Nijmegen Medical Centre, Radboud University Nijmegen Science Faculty and by HEROIC, an Integrated Project funded by the European Union under the 6th Framework Program (LSHG-CT-2005-018883) EU-FP6 Integrated Project.

\section{Acknowledgements}

The authors would like to thank Dr G Veenstra for critical reading of the manuscript.

\section{References}

Ahmed S, Thomas G, Ghoussaini M, Healey CS, Humphreys MK, Platte R, Morrison J, Maranian M, Pooley KA, Luben R et al. 2009 Newly discovered breast cancer susceptibility loci on 3p24 and 17q23.2. Nature Genetics 41 585-590.

Altucci L, Addeo R, Cicatiello L, Dauvois S, Parker MG, Truss M, Beato M, Sica V, Bresciani F \& Weisz A 1996 $17 \beta$-Estradiol induces cyclin D1 gene transcription, p36D1-p34cdk4 complex activation and p105Rb phosphorylation during mitogenic stimulation of $\mathrm{G}(1)$-arrested human breast cancer cells. Oncogene 12 2315-2324.

Anderson E 2002 The role of oestrogen and progesterone receptors in human mammary development and tumorigenesis. Breast Cancer Research 4 197-201.

Anzick SL, Kononen J, Walker RL, Azorsa DO, Tanner MM, Guan XY, Sauter G, Kallioniemi OP, Trent JM \& Meltzer PS 1997 AIB1, a steroid receptor coactivator amplified in breast and ovarian cancer. Science $\mathbf{2 7 7}$ 965-968.

Avantaggiati ML, Ogryzko V, Gardner K, Giordano A, Levine AS \& Kelly K 1997 Recruitment of p300/CBP in p53-dependent signal pathways. Cell 89 1175-1184.
Bahia H, Ashman JN, Cawkwell L, Lind M, Monson JR, Drew PJ \& Greenman J 2002 Karyotypic variation between independently cultured strains of the cell line MCF-7 identified by multicolour fluorescence in situ hybridization. International Journal of Oncology 20 489-494.

Barkhem T, Haldosén LA, Gustafsson JA \& Nilsson S 2002 pS2 gene expression in HepG2 cells: complex regulation through crosstalk between the estrogen receptor $\alpha$, an estrogen-responsive element, and the activator protein 1 response element. Molecular Pharmacology 61 1273-1283.

Barski A, Cuddapah S, Cui K, Roh TY, Schones DE, Wang Z, Wei G, Chepelev I \& Zhao K 2007 High-resolution profiling of histone methylations in the human genome. Cell 129 823-837.

Bauer UM, Daujat S, Nielsen SJ, Nightingale K \& Kouzarides T 2002 Methylation at arginine 17 of histone $\mathrm{H} 3$ is linked to gene activation. EMBO Reports 3 39-44.

Baylin SB 2005 DNA methylation and gene silencing in cancer. Nature Clinical Practice. Oncology 2 S4-S11.

Belandia B, Orford RL, Hurst HC \& Parker MG 2002 Targeting of SWI/SNF chromatin remodelling complexes to estrogen-responsive genes. EMBO Journal 21 4094-4103.

Bernstein BE, Kamal M, Lindblad-Toh K, Bekiranov S, Bailey DK, Huebert DJ, McMahon S, Karlsson EK, Kulbokas EJ, Gingeras TR et al. 2005 Genomic maps and comparative analysis of histone modifications in human and mouse. Cell 120 169-181.

Bhat-Nakshatri P, Wang G, Appaiah H, Luktuke N, Carroll JS, Geistlinger TR, Brown M, Badve S, Liu Y \& Nakshatri H 2008 AKT alters genome-wide estrogen receptor $\alpha$ binding and impacts estrogen signaling in breast cancer. Molecular and Cellular Biology 28 7487-7503.

Bourdeau V, Deschênes J, Métivier R, Nagai Y, Nguyen D, Bretschneider N, Gannon F, White JH \& Mader S 2004 Genome-wide identification of high-affinity estrogen response elements in human and mouse. Molecular Endocrinology 18 1411-1427.

Brown AM, Jeltsch JM, Roberts M \& Chambon P 1984 Activation of pS2 gene transcription is a primary response to estrogen in the human breast cancer cell line MCF-7. PNAS 81 6344-6348.

Brzozowski AM, Pike AC, Dauter Z, Hubbard RE, Bonn T, Engström O, Ohman L, Greene GL, Gustafsson JA \& Carlquist M 1997 Molecular basis of agonism and antagonism in the oestrogen receptor. Nature $\mathbf{3 8 9}$ 753-758.

Buck MJ \& Lieb JD 2004 ChIP-chip: considerations for the design, analysis, and application of genome-wide chromatin immunoprecipitation experiments. Genomics $\mathbf{8 3}$ 349-360.

Bulyk ML 2006 DNA microarray technologies for measuring protein-DNA interactions. Current Opinion in Biotechnology 17 422-430. 
Burdall SE, Hanby AM, Lansdown MR \& Speirs V 2003 Breast cancer cell lines: friend or foe? Breast Cancer Research 5 89-95.

Carroll JS, Liu XS, Brodsky AS, Li W, Meyer CA, Szary AJ, Eeckhoute J, Shao W, Hestermann EV, Geistlinger TR et al. 2005 Chromosome-wide mapping of estrogen receptor binding reveals long-range regulation requiring the forkhead protein FoxA1. Cell 122 33-43.

Carroll JS, Meyer CA, Song J, Li W, Geistlinger TR, Eeckhoute J, Brodsky AS, Keeton EK, Fertuck KC, Hall GF et al. 2006 Genome-wide analysis of estrogen receptor binding sites. Nature Genetics 38 1289-1297.

Chakravarti D, LaMorte VJ, Nelson MC, Nakajima T, Schulman IG, Juguilon H, Montminy M \& Evans RM 1996 Role of CBP/P300 in nuclear receptor signalling. Nature 383 99-103.

Chambon P, Dierich A, Gaub MP, Jakowlev S, Jongstra J, Krust A, LePennec JP, Oudet P \& Reudelhuber T 1984 Promoter elements of genes coding for proteins and modulation of transcription by estrogens and progesterone. Recent Progress in Hormone Research 40 $1-42$.

Chanrion M, Negre V, Fontaine H, Salvetat N, Bibeau F, Grogan GM, Mauriac L, Katsaros D, Molina F, Theillet C et al. 2008 A gene expression signature that can predict the recurrence of tamoxifen-treated primary breast cancer. Clinical Cancer Research 14 1744-1752.

Charpentier AH, Bednarek AK, Daniel RL, Hawkins KA, Laflin KJ, Gaddis S, MacLeod MC \& Aldaz CM 2000 Effects of estrogen on global gene expression: identification of novel targets of estrogen action. Cancer Research 60 5977-5983.

Chen D, Ma H, Hong H, Koh SS, Huang SM, Schurter BT, Aswad DW \& Stallcup MR 1999 Regulation of transcription by a protein methyltransferase. Science $\mathbf{2 8 4}$ 2174-2177.

Chen D, Huang SM \& Stallcup MR 2000 Synergistic, p160 coactivator-dependent enhancement of estrogen receptor function by CARM1 and p300. Journal of Biological Chemistry 275 40810-40816.

Cheng AS, Jin VX, Fan M, Smith LT, Liyanarachchi S, Yan PS, Leu YW, Chan MW, Plass C, Nephew KP et al. 2006 Combinatorial analysis of transcription factor partners reveals recruitment of c-MYC to estrogen receptor- $\alpha$ responsive promoters. Molecular Cell 21 393-404.

Coser KR, Chesnes J, Hur J, Ray S, Isselbacher KJ \& Shioda T 2003 Global analysis of ligand sensitivity of estrogen inducible and suppressible genes in MCF7/BUS breast cancer cells by DNA microarray. PNAS $\mathbf{1 0 0}$ 13994-13999.

DeNardo DG, Kim HT, Hilsenbeck S, Cuba V, Tsimelzon A \& Brown PH 2005 Global gene expression analysis of estrogen receptor transcription factor cross talk in breast cancer: identification of estrogen-induced/activator protein-1-dependent genes. Molecular Endocrinology 19 $362-378$.
Deschênes J, Bourdeau V, White JH \& Mader S 2007 Regulation of GREB1 transcription by estrogen receptor $\alpha$ through a multipartite enhancer spread over $20 \mathrm{~kb}$ of upstream flanking sequences. Journal of Biological Chemistry 282 17335-17339.

DiRenzo J, Shang Y, Phelan M, Sif S, Myers M, Kingston R \& Brown M 2000 BRG-1 is recruited to estrogenresponsive promoters and cooperates with factors involved in histone acetylation. Molecular and Cellular Biology 20 7541-7549.

Dostie J, Richmond TA, Arnaout RA, Selzer RR, Lee WL, Honan TA, Rubio ED, Krumm A, Lamb J, Nusbaum C et al. 2006 Chromosome conformation capture carbon copy (5C): a massively parallel solution for mapping interactions between genomic elements. Genome Research 16 1299-1309.

Dubik D, Dembinski TC \& Shiu RP 1987 Stimulation of c-myc oncogene expression associated with estrogeninduced proliferation of human breast cancer cells. Cancer Research 47 6517-6521.

Frasor J, Danes JM, Komm B, Chang KC, Lyttle CR \& Katzenellenbogen BS 2003 Profiling of estrogen up- and down-regulated gene expression in human breast cancer cells: insights into gene networks and pathways underlying estrogenic control of proliferation and cell phenotype. Endocrinology $1444562-4574$.

Frasor J, Chang EC, Komm B, Lin CY, Vega VB, Liu ET, Miller LD, Smeds J, Bergh J \& Katzenellenbogen BS 2006 Gene expression preferentially regulated by tamoxifen in breast cancer cells and correlations with clinical outcome. Cancer Research 66 7334-7340.

Frønsdal K, Engedal N, Slagsvold T \& Saatcioglu F 1998 CREB binding protein is a coactivator for the androgen receptor and mediates cross-talk with AP-1. Journal of Biological Chemistry 273 31853-31859.

Fullwood MJ \& Ruan Y 2009 ChIP-based methods for the identification of long-range chromatin interactions. Journal of Cellular Biochemistry 107 30-39.

Garcia-Bassets I, Kwon YS, Telese F, Prefontaine GG, Hutt KR, Cheng CS, Ju BG, Ohgi KA, Wang J, Escoubet-Lozach L et al. 2007 Histone methylationdependent mechanisms impose ligand dependency for gene activation by nuclear receptors. Cell 128 505-518.

Gaub MP, Bellard M, Scheuer I, Chambon P \& SassoneCorsi P 1990 Activation of the ovalbumin gene by the estrogen receptor involves the fos-jun complex. Cell $\mathbf{6 3}$ 1267-1276.

Girault I, Lerebours F, Amarir S, Tozlu S, Tubiana-Hulin M, Lidereau R \& Bièche I 2003 Expression analysis of estrogen receptor $\alpha$ coregulators in breast carcinoma: evidence that NCOR1 expression is predictive of the response to tamoxifen. Clinical Cancer Research 9 1259-1266.

Glidewell-Kenney C, Weiss J, Lee EJ, Pillai S, Ishikawa T, Ariazi EA \& Jameson JL 2005 ERE-independent ER $\alpha$ target genes differentially expressed in human breast tumors. Molecular and Cellular Endocrinology 245 53-59. 
Gnanapragasam VJ, Leung HY, Pulimood AS, Neal DE \& Robson CN 2001 Expression of RAC 3, a steroid hormone receptor co-activator in prostate cancer. British Journal of Cancer 85 1928-1936.

Gräf S, Nielsen FG, Kurtz S, Huynen MA, Birney E, Stunnenberg H \& Flicek P 2007 Optimized design and assessment of whole genome tiling arrays. Bioinformatics 23 i195-i204.

Green S, Walter P, Kumar V, Krust A, Bornert JM, Argos P \& Chambon P 1986 Human oestrogen receptor cDNA: sequence, expression and homology to v-erb-A. Nature 320 134-139.

Greene GL, Gilna P, Waterfield M, Baker A, Hort Y \& Shine J 1986 Sequence and expression of human estrogen receptor complementary DNA. Science 231 1150-1154.

Hanlon SE \& Lieb JD 2004 Progress and challenges in profiling the dynamics of chromatin and transcription factor binding with DNA microarrays. Current Opinion in Genetics and Development 14 697-705.

Hayward MA, Brock ML \& Shapiro DJ 1982 Activation of vitellogenin gene transcription is a direct response to estrogen in Xenopus laevis liver. Nucleic Acids Research 10 8273-8284.

Hu X \& Lazar MA 1999 The CoRNR motif controls the recruitment of corepressors by nuclear hormone receptors. Nature 402 93-96.

Hu Q, Kwon YS, Nunez E, Cardamone MD, Hutt KR, Ohgi KA, Garcia-Bassets I, Rose DW, Glass CK, Rosenfeld MG et al. 2008 Enhancing nuclear receptorinduced transcription requires nuclear motor and LSD1-dependent gene networking in interchromatin granules. PNAS 105 19199-19204.

Hurtado A, Holmes KA, Geistlinger TR, Hutcheson IR, Nicholson RI, Brown M, Jiang J, Howat WJ, Ali S \& Carroll JS 2008 Regulation of ERBB2 by oestrogen receptor-PAX2 determines response to tamoxifen. Nature 456 663-666.

Im JY, Park H, Kang KW, Choi WS \& Kim HS 2008 Modulation of cell cycles and apoptosis by apicidin in estrogen receptor (ER)-positive and-negative human breast cancer cells. Chemico-Biological Interactions 172 235-244.

Jakowlew SB, Breathnach R, Jeltsch JM, Masiakowski P \& Chambon P 1984 Sequence of the pS2 mRNA induced by estrogen in the human breast cancer cell line MCF-7. Nucleic Acids Research 12 2861-2878.

Jansen MP, Foekens JA, van Staveren IL, Dirkzwager-Kiel MM, Ritstier K, Look MP, Meijer-van Gelder ME, Sieuwerts AM, Portengen H, Dorssers LC et al. 2005 Molecular classification of tamoxifen-resistant breast carcinomas by gene expression profiling. Journal of Clinical Oncology 23 732-740.

Jensen EV, Block GE, Smith S, Kyser K \& DeSombre ER 1971 Estrogen receptors and breast cancer response to adrenalectomy. National Cancer Institute Monograph 34 55-70.
Jenuwein T \& Allis CD 2001 Translating the histone code. Science 293 1074-1080.

Jin VX, Leu YW, Liyanarachchi S, Sun H, Fan M, Nephew KP, Huang TH \& Davuluri RV 2004 Identifying estrogen receptor $\alpha$ target genes using integrated computational genomics and chromatin immunoprecipitation microarray. Nucleic Acids Research 32 6627-6635.

John S, Sabo PJ, Johnson TA, Sung MH, Biddie SC, Lightman SL, Voss TC, Davis SR, Meltzer PS, Stamatoyannopoulos JA et al. 2008 Interaction of the glucocorticoid receptor with the chromatin landscape. Molecular Cell 29 611-624.

Jost JP, Seldran M \& Geiser M 1984 Preferential binding of estrogen-receptor complex to a region containing the estrogen-dependent hypomethylation site preceding the chicken vitellogenin II gene. PNAS 81 429-433.

Ju BG, Lunyak VV, Perissi V, Garcia-Bassets I, Rose DW, Glass CK \& Rosenfeld MG 2006 A topoisomerase II $\beta$ mediated dsDNA break required for regulated transcription. Science 312 1798-1802.

Kaczynski J, Cook T \& Urrutia R 2003 Sp1- and Krüppel-like transcription factors. Genome Biology 4206.

Kalaitzidis D \& Gilmore TD 2005 Transcription factor crosstalk: the estrogen receptor and NF-kappaB. Trends in Endocrinology and Metabolism 16 46-52.

Kamei Y, Xu L, Heinzel T, Torchia J, Kurokawa R, Gloss B, Lin SC, Heyman RA, Rose DW, Glass CK et al. 1996

A CBP integrator complex mediates transcriptional activation and AP-1 inhibition by nuclear receptors. Cell 85 403-414.

Kangaspeska S, Stride B, Métivier R, Polycarpou-Schwarz M, Ibberson D, Carmouche RP, Benes V, Gannon F \& Reid G 2008 Transient cyclical methylation of promoter DNA. Nature 452 112-115.

Katzenellenbogen BS 1996 Estrogen receptors: bioactivities and interactions with cell signaling pathways. Biology of Reproduction 54 287-293.

Kininis M, Chen BS, Diehl AG, Isaacs GD, Zhang T, Siepel AC, Clark AG \& Kraus WL 2007 Genomic analyses of transcription factor binding, histone acetylation, and gene expression reveal mechanistically distinct classes of estrogen-regulated promoters. Molecular and Cellular Biology 27 5090-5104.

Klein-Hitpass L, Schorpp M, Wagner U \& Ryffel GU 1986 An estrogen-responsive element derived from the $5^{\prime}$ flanking region of the Xenopus vitellogenin A2 gene functions in transfected human cells. Cell $\mathbf{4 6}$ 1053-1061.

Klinge CM 2000 Estrogen receptor interaction with co-activators and co-repressors. Steroid 65 227-251.

Kok M, Linn SC, Van Laar RK, Jansen MP, van den Berg TM, Delahaye LJ, Glas AM, Peterse JL, Hauptmann M, Foekens JA et al. 2009 Comparison of gene expression profiles predicting progression in breast cancer patients treated with tamoxifen. Breast Cancer Research and Treatment 113 275-283. 
Krum SA, Miranda-Carboni GA, Lupien M, Eeckhoute J, Carroll JS \& Brown M 2008 Unique ER $\alpha$ cistromes control cell type-specific gene regulation. Molecular Endocrinology 22 2393-2406.

Kumar V, Green S, Stack G, Berry M, Jin JR \& Chambon P 1987 Functional domains of the human estrogen receptor. Cell 51 941-951.

Kurebayashi J, Otsuki T, Kunisue H, Tanaka K, Yamamoto S \& Sonoo H 2000 Expression levels of estrogen receptor- $\alpha$, estrogen receptor- $\beta$, coactivators, and corepressors in breast cancer. Clinical Cancer Research 6 512-518.

Kwon YS, Garcia-Bassets I, Hutt KR, Cheng CS, Jin M, Liu D, Benner C, Wang D, Ye Z, Bibikova M et al. 2007 Sensitive ChIP-DSL technology reveals an extensive estrogen receptor $\alpha$-binding program on human gene promoters. PNAS 104 4852-4857.

Labhart P, Karmakar S, Salicru EM, Egan BS, Alexiadis V, O'Malley BW \& Smith CL 2005 Identification of target genes in breast cancer cells directly regulated by the SRC3/AIB1 coactivator. PNAS 102 1339-1344.

Laganière J, Deblois G, Lefebvre C, Bataille AR, Robert F \& Giguère V 2005 From the cover: location analysis of estrogen receptor $\alpha$ target promoters reveals that FOXA1 defines a domain of the estrogen response. PNAS 102 11651-11656.

Lai EC, Riser ME \& O’Malley BW 1983 Regulated expression of the chicken ovalbumin gene in a human estrogen-responsive cell line. Journal of Biological Chemistry 258 12693-12701.

Lin CY, Ström A, Vega VB, Kong SL, Yeo AL, Thomsen JS, Chan WC, Doray B, Bangarusamy DK, Ramasamy A et al. 2004 Discovery of estrogen receptor $\alpha$ target genes and response elements in breast tumor cells. Genome Biology 5 R66.

Lin CY, Vega VB, Thomsen JS, Zhang T, Kong SL, Xie M, Chiu KP, Lipovich L, Barnett DH, Stossi F et al. 2007 Whole-genome cartography of estrogen receptor $\alpha$ binding sites. PLoS Genetics 3 e87.

Lippman ME, Rae JM \& Chinnaiyan AM 2008 An expression signature of estrogen-regulated genes predicts disease-free survival in tamoxifen-treated patients better than progesterone receptor status. Transactions of the American Clinical and Climatological Association 119 77-90.

Liu XF \& Bagchi MK 2004 Recruitment of distinct chromatinmodifying complexes by tamoxifen-complexed estrogen receptor at natural target gene promoters in vivo. Journal of Biological Chemistry 279 15050-15058.

Liu Y, Gao H, Marstrand TT, Ström A, Valen E, Sandelin A, Gustafsson JA \& Dahlman-Wright K 2008 The genome landscape of ER $\alpha$ - and ER $\beta$-binding DNA regions. PNAS 105 2604-2609.

Lupien M, Eeckhoute J, Meyer CA, Wang Q, Zhang Y, Li W, Carroll JS, Liu XS \& Brown M 2008 FoxA1 translates epigenetic signatures into enhancer-driven lineagespecific transcription. Cell 132 958-970.
Ma H, Baumann CT, Li H, Strahl BD, Rice R, Jelinek MA, Aswad DW, Allis CD, Hager GL \& Stallcup MR 2001

Hormone-dependent, CARM1-directed, arginine-specific methylation of histone $\mathrm{H} 3$ on a steroid-regulated promoter. Current Biology 11 1981-1985.

Ma XJ, Wang Z, Ryan PD, Isakoff SJ, Barmettler A, Fuller A, Muir B, Mohapatra G, Salunga R, Tuggle JT et al. 2004 A two-gene expression ratio predicts clinical outcome in breast cancer patients treated with tamoxifen. Cancer Cell 5 607-616.

Marks H, Chow JC, Denissov S, Françoijs KJ, Brockdorff N, Heard E \& Stunnenberg HG 2009 High-resolution analysis of epigenetic changes associated with $\mathrm{X}$ inactivation. Genome Research 19 1361-1373.

Massarweh S, Osborne CK, Creighton CJ, Qin L, Tsimelzon A, Huang S, Weiss H, Rimawi M \& Schiff R 2008 Tamoxifen resistance in breast tumors is driven by growth factor receptor signaling with repression of classic estrogen receptor genomic function. Cancer Research 68 826-833.

McGuire WL 1973 Estrogen receptors in human breast cancer. Journal of Clinical Investigation 52 73-77.

Métivier R, Penot G, Hübner MR, Reid G, Brand H, Kos M \& Gannon F 2003 Estrogen receptor- $\alpha$ directs ordered, cyclical, and combinatorial recruitment of cofactors on a natural target promoter. Cell 115 751-763.

Métivier R, Gallais R, Tiffoche C, Le Péron C, Jurkowska RZ, Carmouche RP, Ibberson D, Barath P, Demay F, Reid G et al. 2008 Cyclical DNA methylation of a transcriptionally active promoter. Nature 452 45-50.

Miller TL, Jin Y, Sun JM, Coutts AS, Murphy LC \& Davie JR 1996 Analysis of human breast cancer nuclear proteins binding to the promoter elements of the c-myc gene. Journal of Cellular Biochemistry 60 560-571.

Nagalakshmi U, Wang Z, Waern K, Shou C, Raha D, Gerstein M \& Snyder M 2008 The transcriptional landscape of the yeast genome defined by RNA sequencing. Science 320 1344-1349.

Nielsen R, Pedersen TA, Hagenbeek D, Moulos P, Siersbaek R, Megens E, Denissov S, Børgesen M, Francoijs KJ, Mandrup S et al. 2008 Genome-wide profiling of PPARgamma:RXR and RNA polymerase II occupancy reveals temporal activation of distinct metabolic pathways and changes in RXR dimer composition during adipogenesis. Genes and Development 22 2953-2967.

Oh DS, Troester MA, Usary J, Hu Z, He X, Fan C, Wu J, Carey LA \& Perou CM 2006 Estrogen-regulated genes predict survival in hormone receptor-positive breast cancers. Journal of Clinical Oncology 24 1656-1664.

O’Malley BW, McGuire WL \& Middleton PA 1968 Altered gene expression during differentiation: population changes in hybridizable RNA after stimulation of the chick oviduct with oestrogen. Nature 218 1249-1251.

Osborne CK, Hobbs K \& Trent JM 1987 Biological differences among MCF-7 human breast cancer cell lines from different laboratories. Breast Cancer Research and Treatment 9 111-121. 
Paik S, Shak S, Tang G, Kim C, Baker J, Cronin M, Baehner FL, Walker MG, Watson D, Park T et al. 2004 A multigene assay to predict recurrence of tamoxifentreated, node-negative breast cancer. New England Journal of Medicine 351 2817-2826.

Pan YF, Wansa KD, Liu MH, Zhao B, Hong SZ, Tan PY, Lim KS, Bourque G, Liu ET \& Cheung E 2008 Regulation of estrogen receptor-mediated long range transcription via evolutionarily conserved distal response elements. Journal of Biological Chemistry $\mathbf{2 8 3}$ 32977-32988.

Perillo B, Ombra MN, Bertoni A, Cuozzo C, Sacchetti S, Sasso A, Chiariotti L, Malorni A, Abbondanza C \& Avvedimento EV 2008 DNA oxidation as triggered by H3K9me2 demethylation drives estrogen-induced gene expression. Science 319 202-206.

Perkins ND, Felzien LK, Betts JC, Leung K, Beach DH \& Nabel GJ 1997 Regulation of NF-kappaB by cyclindependent kinases associated with the p300 coactivator. Science 275 523-527.

Petz LN \& Nardulli AM 2000 Sp1 binding sites and an estrogen response element half-site are involved in regulation of the human progesterone receptor a promoter. Molecular Endocrinology 14 972-985.

Pledgie-Tracy A, Sobolewski MD \& Davidson NE 2007 Sulforaphane induces cell type-specific apoptosis in human breast cancer cell lines. Molecular Cancer Therapeutics 6 1013-1021.

Pokholok DK, Harbison CT, Levine S, Cole M, Hannett NM, Lee TI, Bell GW, Walker K, Rolfe PA, Herbolsheimer E et al. 2005 Genome-wide map of nucleosome acetylation and methylation in yeast. Cell 122 517-527.

Qi C, Chang J, Zhu Y, Yeldandi AV, Rao SM \& Zhu YJ 2002 Identification of protein arginine methyltransferase 2 as a coactivator for estrogen receptor $\alpha$. Journal of Biological Chemistry 277 28624-28630.

Rae JM, Johnson MD, Scheys JO, Cordero KE, Larios JM \& Lippman ME 2005 GREB1 is a critical regulator of hormone dependent breast cancer growth. Breast Cancer Research and Treatment 92 141-149.

Roh TY, Ngau WC, Cui K, Landsman D \& Zhao K 2004 High-resolution genome-wide mapping of histone modifications. Nature Biotechnology 22 1013-1016.

Rosenfeld MG, Lunyak VV \& Glass CK 2006 Sensors and signals: a coactivator/corepressor/epigenetic code for integrating signal-dependent programs of transcriptional response. Genes and Development 20 1405-1428.

Ruff M, Gangloff M, Wurtz JM \& Moras D 2000 Estrogen receptor transcription and transactivation: structurefunction relationship in DNA- and ligand-binding domains of estrogen receptors. Breast Cancer Research 2 353-359.

Safe S \& Abdelrahim M 2005 Sp transcription factor family and its role in cancer. European Journal of Cancer 41 2438-2448.
Savouret JF, Rauch M, Redeuilh G, Sar S, Chauchereau A, Woodruff K, Parker MG \& Milgrom E 1994 Interplay between estrogens, progestins, retinoic acid and AP-1 on a single regulatory site in the progesterone receptor gene. Journal of Biological Chemistry 269 28955-28962.

Schübeler D, MacAlpine DM, Scalzo D, Wirbelauer C, Kooperberg C, van Leeuwen F, Gottschling DE, O'Neill LP, Turner BM, Delrow J et al. 2004 The histone modification pattern of active genes revealed through genome-wide chromatin analysis of a higher eukaryote. Genes and Development 18 1263-1271.

Schurter BT, Koh SS, Chen D, Bunick GJ, Harp JM, Hanson BL, Henschen-Edman A, Mackay DR, Stallcup MR \& Aswad DW 2001 Methylation of histone H3 by coactivator-associated arginine methyltransferase 1 . Biochemistry 40 5747-5756.

Shang Y, Hu X, DiRenzo J, Lazar MA \& Brown M 2000 Cofactor dynamics and sufficiency in estrogen receptorregulated transcription. Cell 103 843-852.

Smith CL \& O’Malley BW 2004 Coregulator function: a key to understanding tissue specificity of selective receptor modulators. Endocrine Reviews 25 45-71.

Stender JD, Frasor J, Komm B, Chang KC, Kraus WL \& Katzenellenbogen BS 2007 Estrogen-regulated gene networks in human breast cancer cells: involvement of E2F1 in the regulation of cell proliferation. Molecular Endocrinology 21 2112-2123.

Sultan M, Schulz MH, Richard H, Magen A, Klingenhoff A, Scherf M, Seifert M, Borodina T, Soldatov A, Parkhomchuk D et al. 2008 A global view of gene activity and alternative splicing by deep sequencing of the human transcriptome. Science 321 956-960.

Thomas G, Jacobs KB, Kraft P, Yeager M, Wacholder S, Cox DG, Hankinson SE, Hutchinson A, Wang Z, Yu K et al. 2009 A multistage genome-wide association study in breast cancer identifies two new risk alleles at 1p11.2 and 14q24.1 (RAD51L1). Nature Genetics 41 579-584.

Umayahara Y, Kawamori R, Watada H, Imano E, Iwama N, Morishima T, Yamasaki Y, Kajimoto Y \& Kamada T 1994 Estrogen regulation of the insulin-like growth factor I gene transcription involves an AP-1 enhancer. Journal of Biological Chemistry 269 16433-16442.

van't Veer LJ, Dai H, van de Vijver MJ, He YD, Hart AA, Mao M, Peterse HL, van der Kooy K, Marton MJ, Witteveen AT et al. 2002 Gene expression profiling predicts clinical outcome of breast cancer. Nature $\mathbf{4 1 5}$ 530-536.

Vyhlidal C, Samudio I, Kladde MP \& Safe S 2000 Transcriptional activation of transforming growth factor $\alpha$ by estradiol: requirement for both a GC-rich site and an estrogen response element half-site. Journal of Molecular Endocrinology 24 329-338.

Wagner S, Weber S, Kleinschmidt MA, Nagata K \& Bauer UM 2006 SET-mediated promoter hypoacetylation is a prerequisite for coactivation of the estrogen-responsive pS2 gene by PRMT1. Journal of Biological Chemistry $28127242-27250$. 
Wang HG, Huang ZQ, Xia L, Feng Q, ErdjumentBromage H, Strahl BD, Briggs SD, Allis CD, Wong J, Tempst P et al. 2001 Methylation of histone H4 at arginine 3 facilitating transcriptional activation by nuclear hormone receptor. Science 293 853-857.

Wang Y, Klijn JG, Zhang Y, Sieuwerts AM, Look MP, Yang F, Talantov D, Timmermans M, Meijer-van Gelder ME, Yu J et al. 2005 Gene-expression profiles to predict distant metastasis of lymph-node-negative primary breast cancer. Lancet 365 671-679.

Warner M \& Gustafsson J 2006 Nongenomic effects of estrogen: why all the uncertainty? Steroids.

Welboren WJ, van Driel MA, Janssen-Megens EM, van Heeringen SJ, Sweep FCGJ, Span PN \& Stunnenberg HG 2009 ChIP-Seq of ER $\alpha$ and RNA polymerase II defines genes differentially responding to ligands. EMBO Journal 28 1418-1428.

Wilhelm BT, Marguerat S, Watt S, Schubert F, Wood V, Goodhead I, Penkett CJ, Rogers J \& Bähler J 2008 Dynamic repertoire of a eukaryotic transcriptome surveyed at singlenucleotide resolution. Nature 453 1239-1243.

Wilson IM, Davies JJ, Weber M, Brown CJ, Alvarez CE, MacAulay C, Schübeler D \& Lam WL 2006 Epigenomics: mapping the methylome. Cell Cycle 5 155-158.
Wu J, Smith LT, Plass C \& Huang TH 2006 ChIP-chip comes of age for genome-wide functional analysis. Cancer Research 66 6899-6902.

Yao TP, Oh SP, Fuchs M, Zhou ND, Ch'ng LE, Newsome D, Bronson RT, Li E, Livingston DM \& Eckner R 1998 Gene dosage-dependent embryonic development and proliferation defects in mice lacking the transcriptional integrator p300. Cell 93 361-372.

Zhang Y, Sieuwerts AM, McGreevy M, Casey G, Cufer T, Paradiso A, Harbeck N, Span PN, Hicks DG, Crowe J et al. 2009 The 76-gene signature defines high-risk patients that benefit from adjuvant tamoxifen therapy. Breast Cancer Research and Treatment 116 303-309.

Zhao Z, Tavoosidana G, Sjölinder M, Göndör A, Mariano P, Wang S, Kanduri C, Lezcano M, Sandhu KS, Singh U et al. 2006 Circular chromosome conformation capture (4C) uncovers extensive networks of epigenetically regulated intra- and interchromosomal interactions. Nature Genetics 38 1341-1347.

Zheng W, Long J, Gao YT, Li C, Zheng Y, Xiang YB, Wen W, Levy S, Deming SL, Haines JL et al. 2009 Genome-wide association study identifies a new breast cancer susceptibility locus at 6q25.1. Nature Genetics $41324-328$. 